\title{
CLDN6 wt Allele
}

National Cancer Institute

\section{Source}

National Cancer Institute. CLDN6 wt Allele. NCI Thesaurus. Code C117144.

Human CLDN6 wild-type allele is located in the vicinity of $16 \mathrm{p} 13.3$ and is approximately 5 $\mathrm{kb}$ in length. This allele, which encodes claudin- 6 protein, plays a role in cell-cell adhesion. 